\title{
$\mathrm{CD} 5$ 음성 만성림프구백혈병 1예
}

울산대학교 의과대학 ${ }^{1}$ 서울아산병원 진단검사의학교실, ${ }^{2}$ 강릉아산병원 진단검사의학교실,

${ }^{3}$ 서울아산병원 병리학교실, ${ }^{4}$ 서울아산병원 내과학교실

황금록 $^{1} \cdot$ 박찬정 $^{1} \cdot$ 박서진 $^{1} \cdot$ 장성수 $^{1} \cdot$ 지현숙 $^{1} \cdot$ 차충환 $^{2} \cdot$ 허주영 $^{3} \cdot$ 서철원 $^{4}$

\section{A Case of CD5 Negative Chronic Lymphocytic Leukemia}

Keumrock Hwang, M.D. ${ }^{1}$, Chan-Jeoung Park, M.D. ${ }^{1}$, Seo-jin Park, M.D. ${ }^{1}$, Sungsoo Jang, M.D. ${ }^{1}$, Hyun-Sook Chi, M.D. ${ }^{1}$, Choong-Hwan Cha, M.D. ${ }^{2}$, Joo Ryung Huh, M.D. ${ }^{3}$ and Cheol Won Suh, M.D. ${ }^{4}$

Department of Laboratory Medicine, University of Ulsan College of Medicine, 'Asan Medical Center, Seoul, ${ }^{2}$ Gangnung Asan Hospital, Gangnung, Departments of ${ }^{3}$ Pathology, ${ }^{4}$ Internal Medicine,

University of Ulsan College of Medicine and Asan Medical Center, Seoul, Korea

Neoplastic lymphoid cells of chronic lymphocytic leukemia (CLL) typically co-express CD5 and CD23. CD5-negative CLL is a rare variant of CLL; only 1 case of it has been reported in Korea. We describe a case of CD5-negative CLL. A 48-year-old female complained of a palpable neck mass that had been present for over 1 year. The initial WBC count was $7,300 / \mu \mathrm{L}$, with $69 \%$ lymphocytes. A CT scan revealed multiple enlarged lymph nodes, both of each in the neck, axilla, and common iliac areas. The athologic results of the cervical lymph node was consistent with small lymphocytic lymphoma, of which tumor cells do not express CD5. In a bone marrow study, neoplastic lymphoid cells comprise $34.8 \%$ of all nucleated cells, which showed small size, round nuclei with clumped chromatin, and sparse cytoplasm. Immunophenotyping of small lymphoid cells displayed phenotypes that were CD45-, CD23-, CD20-, and CD19-positive, but CD5-negative. The patient was diagnosed with CD5-negative CLL, and has been followed up for 2.5 years after chemotherapy. (Korean J Hematol 2009;44:255-260.)

Key Words: Chronic lymphocytic leukemia, CD5 antigen, Immunophenotyping

\section{서 론}

만성림프구백혈병은 서구사회에서 가장 흔한 백혈병 으로 전체 백혈병의 약 $30 \%$ 를 차지하지만, ${ }^{1)}$ 국내에서 는 전체 백혈병의 약 $0.5 \sim 5.4 \%$ 를 차지하는 비교적 드 문 종양이다. ${ }^{2)}$ 만성림프구백혈병은 소림프구림프종과 조직학적으로 동일한 질환으로 말초 혈액 림프구수가 $5,000 / \mu \mathrm{L}$ 이상일 때 진단된다. ${ }^{3)}$ 전형적인 만성림프구 백혈병 세포는 크기가 작고 형태학적으로 성숙한 클론

접수 : 2009년 10월 7일, 수정 : 2009년 12월 19일 승인 : 2009년 12월 21일

교신저자 : 박찬정, 서울시 송파구 아산병원길 86

(ㅇ) 138-736, 서울아산병원 진단검사의학과

Tel: 02-3010-4508, Fax: 02-478-0884

E-mail: cjpark@amc.seoul.kr
성 $\mathrm{B}$ 세포로써 세포표면에 $\mathrm{CD} 5$ 와 $\mathrm{CD} 23$ 를 동시에 발현 하며, CD19, CD20, CD22, CD79b 및 세포 표면 면역글 로불린(kappa 혹은 lambda) 약양성, $\mathrm{FMC7}, \mathrm{CD} 10$ 및 Cyclin D1 음성의 면역표현형을 보인다. ${ }^{4}$ 만성림프구 백혈병의 형태학적 소견과 면역표현형 및 임상양상을 보이면서 CD5 항원을 표현하지 않는 CD5 음성 만성림 프구백혈병은 만성림프구백혈병의 드문 아형으로 알 려져 있으며,5) 국내에서는 1999년 Kim 등이 보고한 67세 남자 환자의 증례가 유일하다. ${ }^{7)}$ 저자들은 형태학 적으로 전형적인 만성림프구백혈병의 양상을 보이면

\footnotetext{
Correspondence to : Chan-Jeoung Park, M.D.

Department of Laboratory Medicine, Asan Medical Center 86, Asanbyungwon-gil, Songpa-gu, Seoul 138-736, Korea Tel: +82-2-3010-4508, Fax: +82-2-478-0884

E-mail: cjpark@amc.seoul.kr
} 
서 CD5 음성 표현형을 갖는 만성림프구백혈병 환자 1 예를 경험하였기에 문헌고찰과 함께 보고하고자 한다.

\section{증 례}

\section{환 자: 48세, 여자 \\ 주 소: 목의 종괴}

현병력: 환자는 내원 1년 전부터 목의 종창이 있다가 내원 2개월 전부터 양쪽 귀 뒤로 단단한 종괴가 만져 져 타원에서 조직검사 시행 후 악성림프종으로 진단받 고 정밀 검사와 치료를 위해 서울아산병원 종양내과로 전원되었다. 발열이나 야간 발한 및 체중 감소는 없었다.

신체검사소견: 내원 당시 활력징후는 정상이었고 환
자의 의식은 명료하였다. 양쪽 후방 경부 및 악하에 2 $\mathrm{cm}$ 크기의 단단한 림프절이 촉지되었고 압통이나 열 감은 없었다. 복부진찰에서 간과 비장은 만져지지 않 았다.

검사실 소견 및 방사선 검사소견: 내원 당시 시행한 일반혈액검사 결과 백혈구 7,300/ $\mu \mathrm{L}$ (림프구 69\%), 혈색소 $12.9 \mathrm{~g} / \mathrm{dL}$, 혈소판 $160,000 / \mu \mathrm{L}$ 로 림프구증가증 을 보였다. 망상적혈구는 $1.12 \%$ 로 정상소견을 보였다. 일반생화학검사에서 총단백 $7.9 \mathrm{~g} / \mathrm{dL}$ (참고치 $6.0 \sim 8.0$ $\mathrm{g} / \mathrm{dL}$ ), 알부민 $3.9 \mathrm{~g} / \mathrm{dL}$ (참고치 $3.5 \sim 5.2 \mathrm{~g} / \mathrm{dL}$ ), 크레아 티닌 $0.6 \mathrm{mg} / \mathrm{dL}$ (참고치 $0.7 \sim 1.4 \mathrm{mg} / \mathrm{dL}$ ), $\mathrm{LDH} 254$ $\mathrm{IU} / \mathrm{L}$ (참고치 120 250 IU/L), $\beta 2$-microglobulin 2.8 $\mu \mathrm{g} / \mathrm{dL}$ (참고치 $1.0 \sim 2.4 \mu \mathrm{g} / \mathrm{dL}$ )였다. 컴퓨터단층촬영
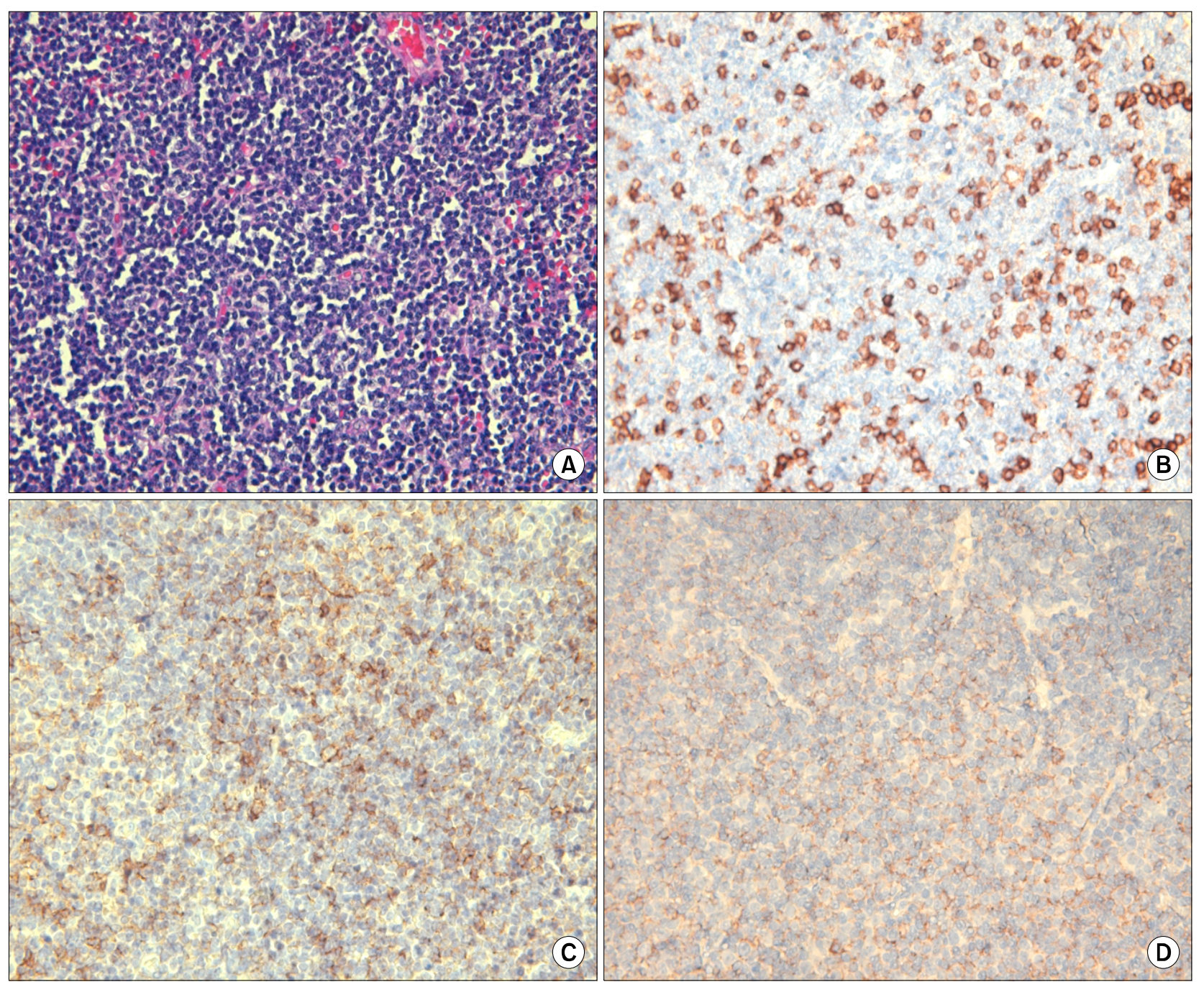

Fig. 1. Cervical lymph node biopsy findings. (A) Diffuse infiltration of small lymphocytes in cervical lymph node (H\&E stain, $\times 400$ ), (B) Negative expression of CD5 on neoplastic lymphoid cells, (C) Positive expression of CD23 on neoplastic lymphoid cells, (D) Weak positive expression of CD20 on neoplastic lymphoid cells (B,C,D: immunohistochemistry on lymph node biopsy section, $\times 400)$. 
에서 양쪽 경부, 양쪽 액와, 오른쪽 기관주위, 양쪽 총 장골림프절(common iliac lymph nodes)에 다발성 종대 가 관찰되었고 전신 양전자방출단층촬영(PET)에서 양 쪽 경부, 쇄골상, 흥근내, 액와, 복부골반 및 서혜부림 프절에 대사가 증가한 병소가 다수 관찰되었다.

조직검사 소견: 경부림프절 생검 결과 형태학적으로 소림프구림프종에 일치하는 소견을 보였고 면역조직 화학염색에서 $\mathrm{CD} 23, \mathrm{CD} 20$ 양성, $\mathrm{CD} 5, \mathrm{CD} 10$, Cyclin D1 및 bcl-6 음성이었고 Ki-67 표지지수는 5\% 미만이 었다(Fig. 1).

골수 흡인 및 생검 소견: 골수 흡인검사에서 종양성 림프구가 전체 유핵세포의 $34.8 \%$ 를 차지하였고 smudge 세포가 빈번히 관찰되었다. 종양성 림프구는 크기가 작고 핵 세포질 비율이 크고 둥근 핵 안에 농축염색질
을 가진 성숙한 림프구의 형태를 보였다. 골수 생검 결 과 세포충실도는 $60 \%$ 였고 종양성 림프구가 결절성 혹 은 간질성으로 침윤되어 있었다(Fig. 2). 골수 흡인 세 포를 이용한 유세포분석에서 종양성 림프구는 $\mathrm{CD} 45$, $\mathrm{CD} 23, \mathrm{CD} 20$ 및 $\mathrm{CD} 19$ 에 양성 소견을 보였으나 $\mathrm{CD}$, $\mathrm{CD} 10, \mathrm{CD} 22, \mathrm{FMC} 7, \mathrm{CD} 3, \mathrm{CD} 7, \mathrm{CD} 56, \mathrm{TdT}$ 및 세포표 면 면역글로불린은 음성이었다(Fig. 3). 세포유전학적 검사를 위해 진단 당시의 골수검체로 분열중기세포 20 개를 분석하였고 $46, X X$ 의 정상 핵형을 보였다.

치료 및 임상경과: 환자는 경부림프절 생검 결과와 골수검사의 형태학적, 면역표현학적 소견에 근거하여 $\mathrm{CD} 5$ 음성 만성림프구백혈병으로 진단되었다. 진단 당 시 수정 Rai 병기로 중등도 위험군이면서 Binet 병기 $\mathrm{B}$ 에 속하여 fludarabine으로 항암치료를 시작하였다.
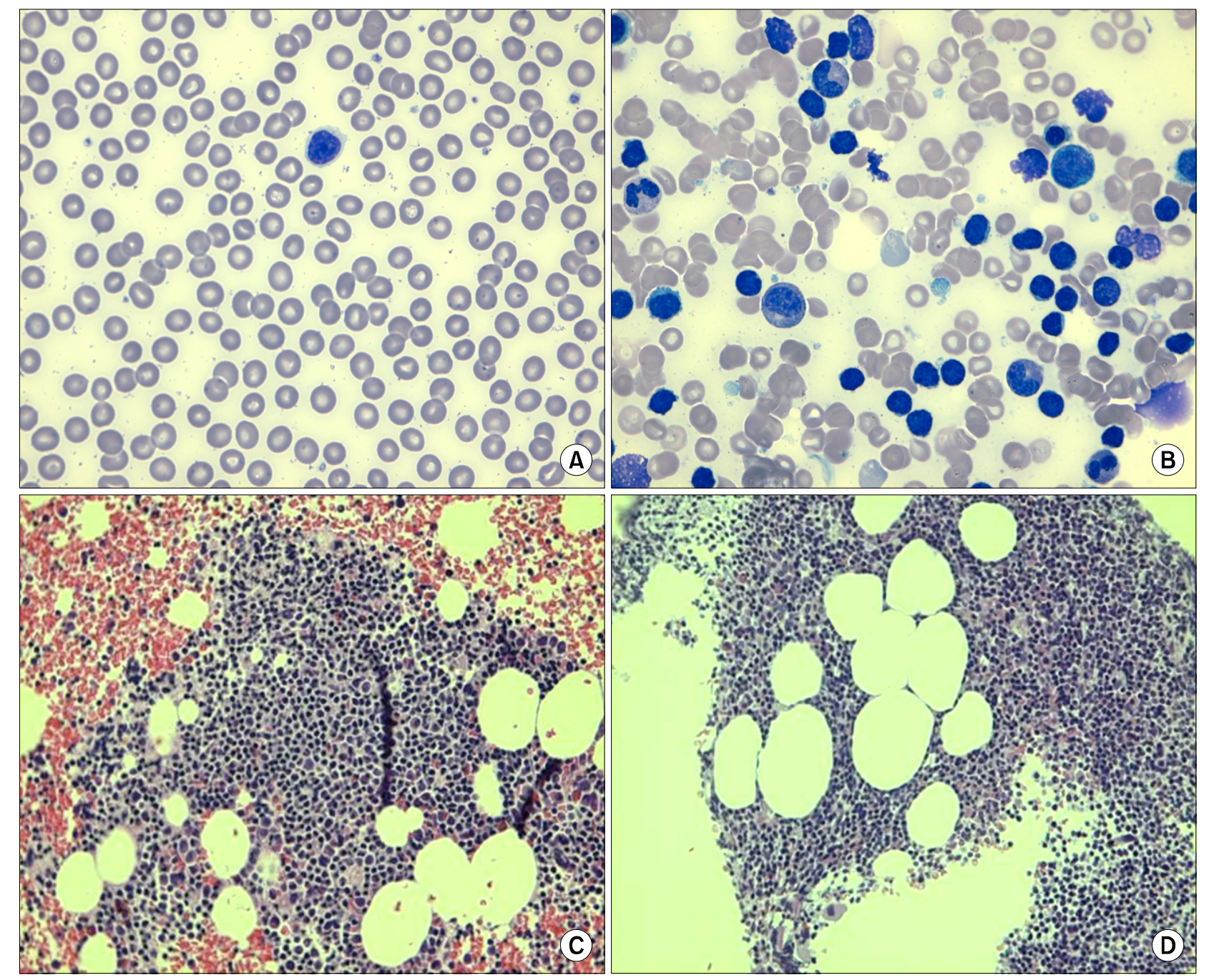

Fig. 2. Peripheral blood, bone marrow aspirate and bone marrow biopsy findings. (A) Small lymphocyte in peripheral blood (Wright stain, $\times 1,000)$, (B) Frequent small lymphocytes in bone marrow aspirate (Wright stain, $\times 1,000$ ), Nodular or interstitial infiltration of small lymphocytes in bone marrow clot section (C) and bone marrow biopsy (D) (H\&E stain, $\times 400)$. 

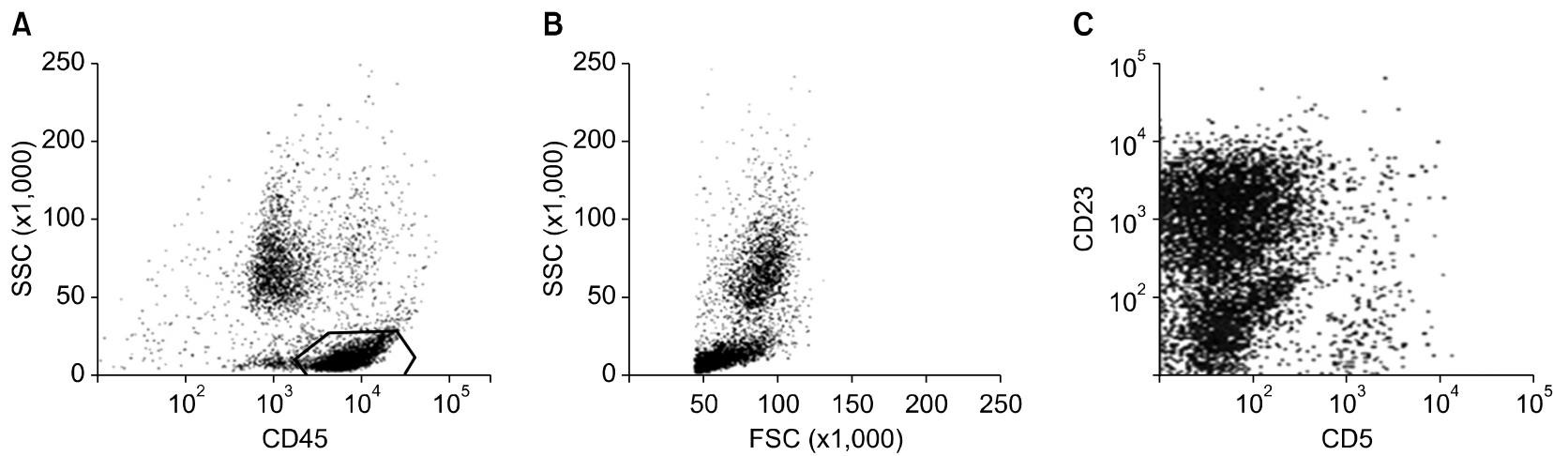

Fig. 3. Immunophenotyping of bone marrow aspirate. (A) Gating of nucleated cells expressing bright CD45 and low SSC, (B) Gated cells are small mononucleated cells, (C) Gated cells show CD23 positivity and CD5 negativity.

이 후 cyclophosphamide, doxorubicin, vincristine, prednisolone 조합 및 cyclophosphamide, vincristine, prednisolone 조합의 항암치료를 각각 6회씩 시행하였다. 항암치료 후 일반혈액검사에서 백혈구 2,300/ $\mu \mathrm{L}$ (절 대호중구수 $1,024 / \mu \mathrm{L}$ ), 혈색소 $12.2 \mathrm{~g} / \mathrm{dL}$, 혈소판 $123,000 / \mu \mathrm{L}$ 로 호중구감소증은 지속되었지만, 골수검 사 결과 종양성 림프구는 관찰되지 않았다. 환자는 부 분관해에 도달한 후 더 이상 질병이 진행하지 않는 상 태로 진단 후 2년 6개월 동안 본원 종양내과 외래에서 추적관찰 중이다.

\section{고 찰}

$\mathrm{CD} 5$ 는 범 $\mathrm{T}$ 세포 항원으로써 정상 성인 말초혈액 $\mathrm{B}$ 세포의 약 $1 \sim 7 \%$ 에서 양성으로 표현되는데, ${ }^{8)}$ 만성림 프구백혈병과 외투세포림프종(mantle cell lymphoma) 및 변연부림프종(marginal zone lymphoma)의 일부에 서 양성으로 표현된다. ${ }^{1,9)}$ 특히 CD5는 만성림프구백혈 병의 진단에 가장 중요한 항원으로 여겨져 왔으며, ${ }^{6)}$ Matutes 등은 만성림프구백혈병의 진단을 위해 CD5와 $\mathrm{CD} 22, \mathrm{CD} 23, \mathrm{FMC} 7$, 세포표면 면역글로불린의 표현 정도 및 면역염색 강도를 기초로 한 점수제를 제안하 였다. ${ }^{10)} \mathrm{CD} 5$ 항원을 표현하지 않는 만성림프구백혈병 은 전체 만성림프구백혈병의 $2 \%$ 이하를 차지하는 매 우 드문 아형으로 알려져 있는데, 문헌에 따라서는 $\mathrm{CD} 5$ 음성 만성림프구백혈병이 만성림프구백혈병의 최대 $36 \%$ 를 차지한다는 보고도 있다. ${ }^{8,9)} \mathrm{CD} 5$ 음성 만 성림프구백혈병의 국내 보고는 지금까지 1 예에 불과 하여 CD5 음성 만성림프구백혈병의 빈도와 임상상이 잘 알려져 있지 않다. ${ }^{7)}$

$\mathrm{CD} 5$ 음성 만성림프구백혈병은 CD5 양성의 전형적
인 만성림프구백혈병과 다른 임상적 경과를 보이는 것 으로 알려져 있다. ${ }^{5,6)}$ 이전 국외보고에 따르면 CD5 음 성 만성림프구백혈병은 일반적으로 전형적인 만성림 프구백혈병보다 더 불량한 예후를 보인다. ${ }^{1,5,6)}$ 미국과 유럽에서 보고된 CD5 음성 만성림프구백혈병은 진단 당시 림프절종창과 간비종대가 심하고, 림프구증가증, 빈혈 및 혈소판감소증이 심하며 급격한 임상 경과와 나쁜 예후를 보이는 경우가 많았다. ${ }^{6,8,11)}$ 한편, 일본에 서 보고된 CD5 음성 만성림프구백혈병 2증례는 경한 임상증상과 느린 질병경과를 보였으며, ${ }^{5,12}$ 1999년 국 내 증례의 환자는 체중감소가 심하고 다발성 림프절종 대와 비장종대가 관찰되었으나 항암치료 후 부분관해 상태를 유지하며 질병의 진행이 없었다. ${ }^{7)}$ 본 증례의 환자는 진단 당시 림프구수가 $5,039 / \mu \mathrm{L}$ 였고 빈혈 및 혈소판감소증은 심하지 않았으며 전신에 다발성 림프 절종창이 있었지만 간비종대는 없었다. 환자는 항암치 료 후 2년 6개월에 이르는 현재까지 부분관해 상태를 유지면서 더 이상 질병이 진행하지 않았다. 이처럼, 국 내와 일본에서 보고된 CD5 음성 만성림프구백혈병은 서구에서 보고된 증례에서 보다 좀더 완만한 임상경과 를 보이는 경향이 있었는데, CD5 음성 만성림프구백 혈병의 지역간 인종간 임상상의 차이를 증명하기 위해 서는 더 많은 증례의 비교가 필요하며 정확한 진단이 뒷받침되어야 할 것으로 사료된다.

한편, 임상소견이 경하고 질병의 진행이 느린 CD5 음성 만성림프구백혈병의 일부는 만성림프구백혈병이 아닌 양성 림프구증가증일 수 있다. 2002년 Wang 등은 형태학적으로 만성림프구백혈병과 유사한 단클론성 $\mathrm{B}$-림프구증가증이 있고 $\mathrm{CD} 19, \mathrm{CD} 20$ 양성이며 경쇄 제 한(light chain restriction)이 있으나 CD5, CD10 및 $\mathrm{CD} 23$ 음성이며, 림프절종창이나 간비종대가 뚜렷하지 
않고 정상 핵형을 갖는 경우를 monoclonal lymphocytosis of undetermined significance (MLUS)로 구분하였 다. ${ }^{11)}$ MLUS는 형태학적으로 만성림프구백혈병과 유 사하여 CD5 음성 만성림프구백혈병으로 오인할 수 있 지만 질병이 진행하지 않는 양성 림프구증가증이므로 $\mathrm{CD} 5$ 음성 만성림프구백혈병을 진단할 때 유의하여야 한다. ${ }^{13)}$ 증례의 환자는 형태학적으로 성숙한 림프구증 가증이 있으면서 $\mathrm{CD} 5$ 음성의 비특이적 면역표현형을 보였지만, MLUS와는 달리 CD23 양성 면역표현형을 보였으며 신체검사, 컴퓨터단층촬영 및 양전자방출단 층촬영에서 전신에 다발성의 림프절종대가 관찰되어 MLUS를 배제할 수 있었다.

기본 핵형검사 상 만성림프구백혈병 환자의 약 $50 \%$ 가량에서 염색체 이상을 보이는데, 주로 염색체의 소 실이나 획득과 관련된 이상이 흔하여, $\operatorname{del}(13)(q 14)$, $\operatorname{del}(11)(q 23),+12, \operatorname{del}(17)(q 13), \operatorname{del}(6)(q 21)$ 등의 염 색체 이상이 빈번히 관찰된다.,14) 2002년 Specchia 등 이 $3 \mathrm{q}$ 사염색체성 및 18 삼염색체성 핵형을 보이는 CD5 음성 만성림프구백혈병환자를 보고한 예가 있지 만, ${ }^{14)}$ 현재까지 $\mathrm{CD} 5$ 음성 만성림프구백혈병에 특이적 으로 나타나는 염색체이상은 알려져 있지 않다. 본 증 례의 환자는 기본 핵형검사에서 $46, \mathrm{XX}$ 의 정상 핵형을 보였는데, 만성림프구백혈병 세포는 유사분열 활동성 이 낮아 분열중기상을 얻기 힘들기 때문에 기본 핵형 검사만으로는 종양세포의 정확한 염색체 이상을 알기 어렵다. CD5 음성 만성림프구백혈병을 진단하기 위해 서는 림프구증가증의 다른 원인을 배제해야 하며 이때 특징적인 염색체 이상소견이 감별진단에 도움이 될 수 있으므로 $\mathrm{CD} 5$ 음성 만성림프구백혈병이 의심될 때는 기본 핵형검사에 더하여 형광제자리부합법을 시행할 필요가 있다.

만성림프구백혈병 세포와 같이 크기가 작고 성숙한 형태를 보이는 림프구가 말초혈액과 골수에 침윤되어 있으면 형태학적인 소견만으로 진단을 내리기 어렵다. 이때 림프구의 면역표현형 검사 및 면역조직화학염색 이 진단에 도움이 되는데, ${ }^{6}$ 만성림프구백혈병 세포의 경우 $\mathrm{CD} 5, \mathrm{CD} 23$ 양성, $\mathrm{CD} 19, \mathrm{CD} 20, \mathrm{CD} 22, \mathrm{CD} 79 \mathrm{~b}$ 및 세포 표면 면역글로불린 약양성, $\mathrm{FMC7}, \mathrm{CD} 10$ 및 Cyclin D1 음성의 특징적인 면역표현형을 보인다. ${ }^{4)}$ 본 증례 환자의 종양성 림프구는 $\mathrm{CD} 5$ 음성이었지만 $\mathrm{CD} 23$, $\mathrm{CD} 20, \mathrm{CD} 19$ 양성 및 $\mathrm{CD} 10, \mathrm{CD} 22, \mathrm{FMC7}$ 음성으로 $\mathrm{CLL}$ 에 합당한 소견이었고, ${ }^{10)}$ 경부림프절 생검 절편으 로 시행한 면역조직화학염색 상 $\mathrm{CD} 23, \mathrm{CD} 20$ 양성, $\mathrm{CD} 5$, CD10, Cyclin D1, bcl-6 음성 및 Ki-67 표지지수 5\% 미
만으로 다른 B-세포계열 비호치킨림프종을 배제할 수 있었다. 즉, $\mathrm{CD} 23$ 양성으로 변연부림프종을 배제할 수 있고 $\mathrm{CD} 10$ 및 bcl-6 음성으로 소포림프종(follicular lymphoma)을 배제할 수 있으며, Cyclin D1 음성으로 외투세포림프종을 배제하였고, $\mathrm{Ki}-67$ 표지지수 5\% 미 만으로 버킷림프종을 배제하였다. 이처럼 만성림프구 백혈병의 형태학적 특징을 보이면서 CD5 음성의 비전 형적 면역표현형을 갖는 환자에서는 CD5 음성 만성림 프구백혈병으로 진단하기 이전에, 다른 비호치킨림프 종의 백혈병 발현이나 MLUS와 같은 양성 림프구증가 증을 감별해야 한다. 실제로 일부 문헌에서 $\mathrm{CD} 5$ 음성 만성림프구백혈병의 빈도가 만성림프구백혈병의 약 $36 \%$ 를 차지한다고 보고된 것은 $\mathrm{CD} 5$ 음성을 보이는 다 른 질환이 $\mathrm{CD} 5$ 음성 만성림프구백혈병으로 오진되었 기 때문일 수 있다. ${ }^{6}$ 증례의 환자와 같이 진단 당시 면 역표현형검사와 면역조직화학검사에서 CD5가 음성이 어도, 만성림프구백혈병에 특징적인 항원들이 표현되 면서 다른 림프종에 특징적인 항원들이 표현되지 않으 면 진단에 도움이 된다. CD5 음성 만성림프구백혈병 의 확진은 환자의 일반혈액검사, 말초혈액도말, 진찰 소견, 방사선검사, 골수검사 및 유전학적 검사 결과를 종합하여 이루어져야 한다.

\section{요 약}

만성림프구백혈병의 종양 세포는 특징적으로 CD5 와 $\mathrm{CD} 23$ 을 동시에 표현한다. $\mathrm{CD} 5$ 음성 만성림프구백 혈병은 만성림프구백혈병의 드문 아형이며, 국내 보고 는 1예가 유일하다. 저자들은 CD5 음성 표현형을 보이 는 만성림프구백혈병 1 예를 경험하였기에 이를 보고 하고자 한다. 48세 여자가 내원 1년전부터 만져지는 목 의 종괴를 주소로 내원하였다. 내원 당시 백혈구수는 $7,300 / \mu \mathrm{L}$ 로 $69 \%$ 가 림프구였다. 컴퓨터단층촬영에서 양쪽 경부, 양쪽 액와, 양쪽 총장골림프절에 다발성 종 대가 관찰되었다. 경부림프절 생검 결과 CD5가 음성 이었지만 소림프구림프종에 합당한 소견이었다. 골수 검사에서 종양세포는 크기가 작고, 핵이 둥글고 응집 된 염색질을 가진 세포질이 적은 형태를 보였고 유핵 세포의 $34.8 \%$ 를 차지하였다. 면역표현형은 $\mathrm{CD} 45$, $\mathrm{CD} 23, \mathrm{CD} 20, \mathrm{CD} 19$ 양성이었지만 $\mathrm{CD} 5$ 는 음성이었다. 환자는 $\mathrm{CD} 5$ 음성 만성림프구백혈병으로 진단되었고 항암화학요법 후 2년 6개월 동안 추적관찰 중이다. 


\section{참 고 문 헌}

1) Sheikh SS, Kallakury BV, Al-Kuraya KA, Meck J, Hartmann DP, Bagg A. CD5-negative, CD10-negative small B-cell leukemia: variant of chronic lymphocytic leukemia or a distinct entity? Am J Hematol 2002;71:306-10.

2) Kim SI, Cho HI, Park MH. Leukemia and leukemia-related disorders in Korean. Korean J Hematol 1998;23:313-33

3) Hallek M, Cheson BD, Catovsky D, et al. Guidelines for the diagnosis and treatment of chronic lymphocytic leukemia: a report from the international workshop on chronic lymphocytic leukemia updating the national cancer institute-working group 1996 guidelines. Blood 2008;111:5446-56.

4) World Health Organization classification of tumours of haematopoietic and lymphoid tissues. In: MullerHermelink HK, Montserrat E, Catovsky D, eds. Chronic lymphocytic leukemia/small lymphocytic lymphoma. 4th ed. IARC, USA: IARC press, 2008: 180-2.

5) Okamoto M, Nakano S, Namura K, et al. CD5-negative chronic lymphocytic leukemia with indolent clinical course and autoimmune thrombocytopenia, successfully treated with rituximab. Am J Hematol 2004;77: 413-5.

6) Huang JC, Finn WG, Goolsby CL, Variakojis D, Peterson LC. CD5-small B-cell leukemias are rarely classifiable as chronic lymphocytic leukemia. Am J Clin Pathol 1999;111:123-30.
7) Kim OK, Cheon JS, Kim HJ, et al. A case of CD5 Negative B-Cell chronic lymphocytic leukemia. Korean J Med 1999;56:235-9.

8) Cartron G, Linassier C, Bremond JL, et al. CD5 negative B-cell chronic lymphocytic leukemia: clinical and biological features of 42 cases. Leuk Lymphoma 1998;31:209-16.

9) Cavalcanti Junior GB, Sales VS, Cavalcanti e Silva DG, et al. Detection of CD5 in B-cell chronic lymphoproliferative diseases by flow cytometry: a strong expression in B-cell chronic lymphocytic leukemia. Acta Cir Bras 2005;20 Suppl 1:101-7.

10) Matutes E, Owusu-Ankomah K, Morilla R, et al. The immunological profile of B-cell disorders and proposal of a scoring system for the diagnosis of CLL. Leukemia 1994;8:1640-5.

11) Wang C, Amato D, Fernandes B. CD5-negative phenotype of monoclonal B-lymphocytosis of undetermined significance (MLUS). Am J Hematol 2002; 69:147-9.

12) Yamada $T$, Ninomiya $H$, Horiuchi $T$, et al. CD5 negative B-cell chronic lymphocytic leukemia (B-CLL) associated with massive splenomegaly and without lymphadenopathy. Rinsho Ketsueki 1995;36:1230-2.

13) Keung YK, Buss D, Pettenati M, Powell BL. CD5negative chronic lymphocytic leukemia or monoclonal B-lymphocytosis of undetermined significance? Am J Hematol 2002;70:334.

14) Specchia G, Albano F, Anelli L, et al. Concomitant tetrasomy $3 \mathrm{q}$ and trisomy 18 in $\mathrm{CD} 5(-), \operatorname{CD} 13(+)$ chronic lymphocytic leukemia. Cancer Genet Cytogenet 2002;133:160-3. 